\title{
Finding the specific etiology in myocardial infarction with non-obstructive coronary arteries disease (MINOCA) and the best therapeutic approaches -
}

\section{a case report}

\author{
Adriana loana Ardelean ${ }^{1,2}$, Madalina loana Moisi ${ }^{1,2}$, Sabina Belenes ${ }^{2}$, Marius Rus ${ }^{1,3}$, Mircea loachim Popescu ${ }^{1,3}$
}

\begin{abstract}
Myocardial infarction with nonobstructive coronary arteries disease (MINOCA) is defined as a clinical syndrome with normal or near normal coronary arteries disease (stenosis severity revealed on angiography less than $50 \%$ ), excluding other overt causes of myocardial ischemia such as cardiac trauma. Trials report an incidence between $5-10 \%$ among subjects with acute myocardial infarction (AMI). The optimal management and the outcome of this syndrome require the proper identification of the specific pathophysiologic mechanism. We report the case of a 67-year-old male presenting with the clinical and enzymatic picture of a myocardial infarction with ST segment elevation in the anterior territory with no significant coronary arteries stenosis on the angiography. Our case illustrates the importance of revealing the real underlying condition which is involved in producing the MINOCA syndrome, because this is the only strategy suitable for a correct treatment and a favorable outcome.
\end{abstract}

Keywords: MINOCA, angiography, coronary artery stenosis, antiplatelet therapy.

Rezumat: Infarctul miocardic cu artere coronare permeabile (MINOCA) este definit ca un sindrom clinic cu artere coronare normale sau aproape normale (definite prin severitatea stenozei coronariene mai mică de $50 \%$, decelată cu ocazia coronarografiei), excluzând alte cauze de ischemie miocardică, cum ar fi traumatismele cardiace. Studiile au raportat o incidență între 5-10\% în cazul subiecților cu infarct miocardic acut (AMI). Managementul optim și prognosticul acestui sindrom necesită identificarea corespunzătoare a mecanismului fiziopatologic specific. Raportăm cazul unui bărbat în vârstă 76 de ani care prezintă tabloul clinic și enzimatic a unui infarct miocardic cu supradenivelare de segment ST în teritoriul anterior, făă stenoze coronariane semnificativă evidențiate prin coronarografie. Cazul nostru ilustrează importanţa dezvăluirii cauzei reale incriminate în producerea sindromului MINOCA, deoarece aceasta este singura strategie potrivită pentru un tratament corect și o evoluție favorabilă.

Cuvinte-cheie: MINOCA, angiografie, stenoză coronariană, terapie antiplachetară.

\section{INTRODUCTION}

Atherosclerosis represents the main process which may lead to the occlusion of the epicardial arteries in ST-segment-elevation myocardial infarction (STEMI). Usually the presence of the obstructive coronary artery disease is revealed in $95 \%$ of the cases with STEMI and NON-STEMI'.

The intriguing MINOCA syndrome was underdiagnosed in the past because clinicians thought that the

\footnotetext{
' Department of Preclinical Disciplines, Faculty of Medicine and Pharmacy, University of Oradea, Oradea, Romania

${ }^{2}$ Emergency Clinical County Hospital of Oradea, Oradea, Romania

${ }^{3}$ Department of Clinical Disciplines, Faculty of Medicine and Pharmacy,

University of Oradea, Oradea, Romania
}

absence of the obstructive atheromatous plaque or the acute thrombosis represents the exclusion arguments of a true ST-segment-elevation myocardial infarction, leading to a misinformation and assurance of a favorable outcome in these subjects. The whole idea was redefined when the Fourth Universal Definition of the Myocardial Infarction was released in 2018. MINOCA syndrome is defined as the presence of the acute myocardial infarction without significant coro-

\section{Contact address:}

Adriana loana Ardelean, Department of Cardiology, Emergency Clinical County Hospital, 65 Gheorghe Doja Street, 410169, Oradea, Romania. E-mail: adriana_toadere@yahoo.com 
nary artery disease on the angiography. The diagnosis should exclude other overt causes that might cause troponin elevation, like sepsis or pulmonary embolism, Takotsubo syndrome or myocardial cell injury that is not related to ischemia (eg: myocarditis) ${ }^{2}$.

The Vigo study revealed an incidence of MINOCA syndrome of more than $10 \%$ in young patients with acute myocardial infarction. Even if the clinical particularities of the MINOCA subjects differs comparing with the AMI group, the mortality rate at I month and I year are similar proving that the myocardial infarction with nonobstructive coronary artery disease is not a benign condition and further tests should reveal the underlying etiology'.

There are some mechanisms that might be involved in the appearance of the MINOCA syndrome including the atheromatous plaque erosion, embolism or epicardial coronary artery dissection. Other causes refer to a vasospasm of a coronary artery or of the microcirculation.

Besides angiography, the etiological diagnosis could be provided by the echocardiography, intravascular ultrasound, optical coherence tomography ${ }^{2}$. Cardiac magnetic resonance represents an important examination that may reveal late gadolinium enhancement caused by tissue damage due to myocardial infarction ${ }^{3}$.

Coronary CT angiography may be used for identifying of the atherosclerotic marks, with the observation that plaque rupture or erosion cannot be illustrated using this method. Description of normal coronary artery on coronary CT angiography does not guarantee the absence of a thrombotic disease as a main underlying condition for MINOCA occur- rence. This is the reason why the diagnosis should be formulated only if the absence of a stenotic lesion is revealed using the coronary angiography rather than considering the presence of atherosclerosis landmarks described by noninvasive imaging elements for etiological diagnosis of MINOCA ${ }^{3}$.

\section{CASE PRESENTATION}

We report the case of a 67-year-old male, without previous medical history, presenting in the emergency department with chest pain, sweating, accompanied by a new left bundle branch block on the electrocardiography (Figure I). High sensitivity troponin illustrated a high value $(5 / 87 \mathrm{ng} / \mathrm{L})$ and the others biological findings were in normal ranges, except from an elevated blood glucose $(263 \mathrm{mg} / \mathrm{dl})$ and high glycosylated hemoglobin (8.8\%). The echocardiography reflected global hypokinesia of the left ventricle and a severe reduction of ejection fraction (25\%) (Figure 2). Emergency angiography was performed using transradial approach but there were no significant coronary arteries stenosis, with an estimated TIMI flow 3 in all the epicardial coronary arteries (Figure 3 and 4).

Considering the electrocardiographic aspect, corroborated with the elevation of the myocardial necrosis markers and the angiography, we decided that the diagnosis was MINOCA syndrome, which required further investigations. The diagnostic algorithm was completed by cardiac magnetic resonance, an important diagnostic method, which revealed necrosis of the lateral ventricular wall, with no edema or microvascular obstructions. The dilated left ventricle illustrated a depressed ejection fraction on the CMR (43\%), with an

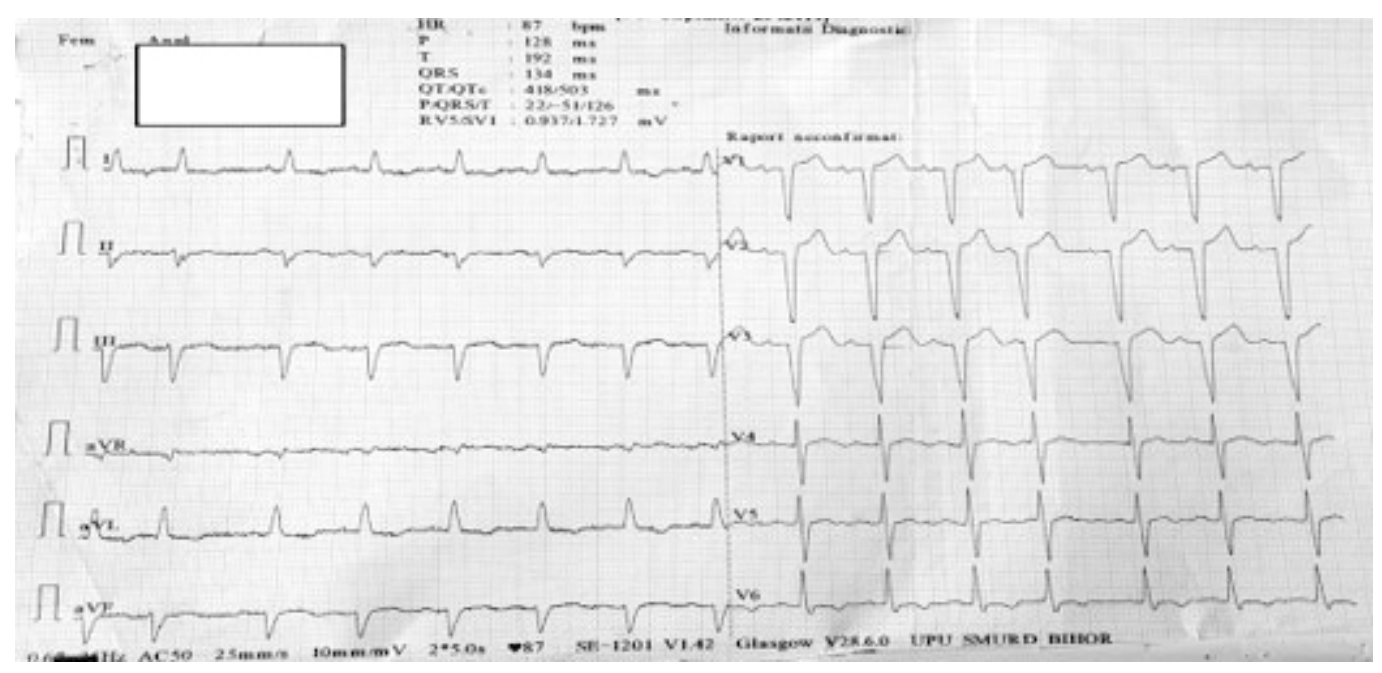

Figure I. Electrocardiogram performed at admission reflects sinus rhythm, 87 beats/minute, left bundle branch block. 
indexed myocardial mass in the normal ranges. Finally, the conclusion emphasized a transmural lateral myocardial infarction in the circumflex coronary artery territory, with no myocardial cells viability (Figure 5).

Analyzing the CMR result and the angiography without relevant coronary arteries stenosis, the conclusion was that exist a certain underlying substrate which is producing a predisposition for thrombosis. We finally performed the genetic tests for detection of the thrombophilia and the result was surprising. The complex profile described a combination of heterozygous and homozygous mutations of the elements involved in the coagulation cascade, predisposing to a prothrombotic status. The heterozygous mutations
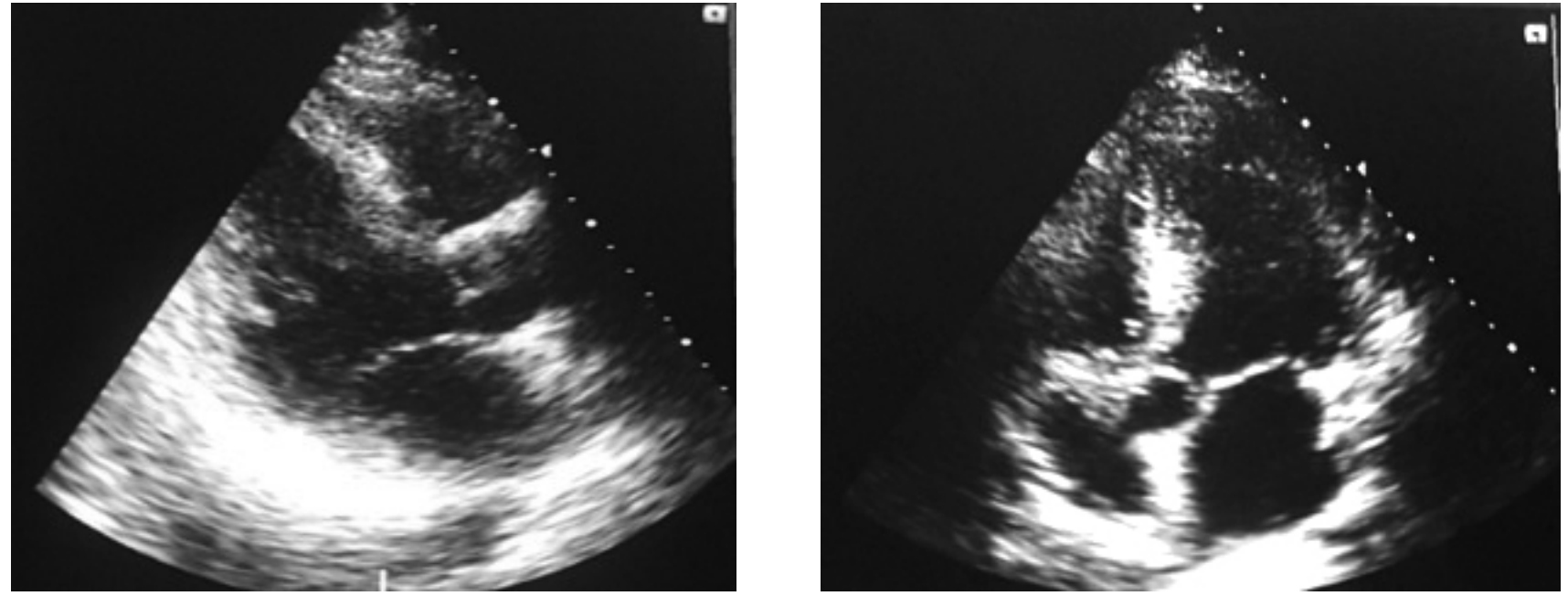

Figure 2. Transthoracic echocardiography: parasternal long axis (right) and apical 5 chambers (left) - reflects dilatation of the left ventricle.

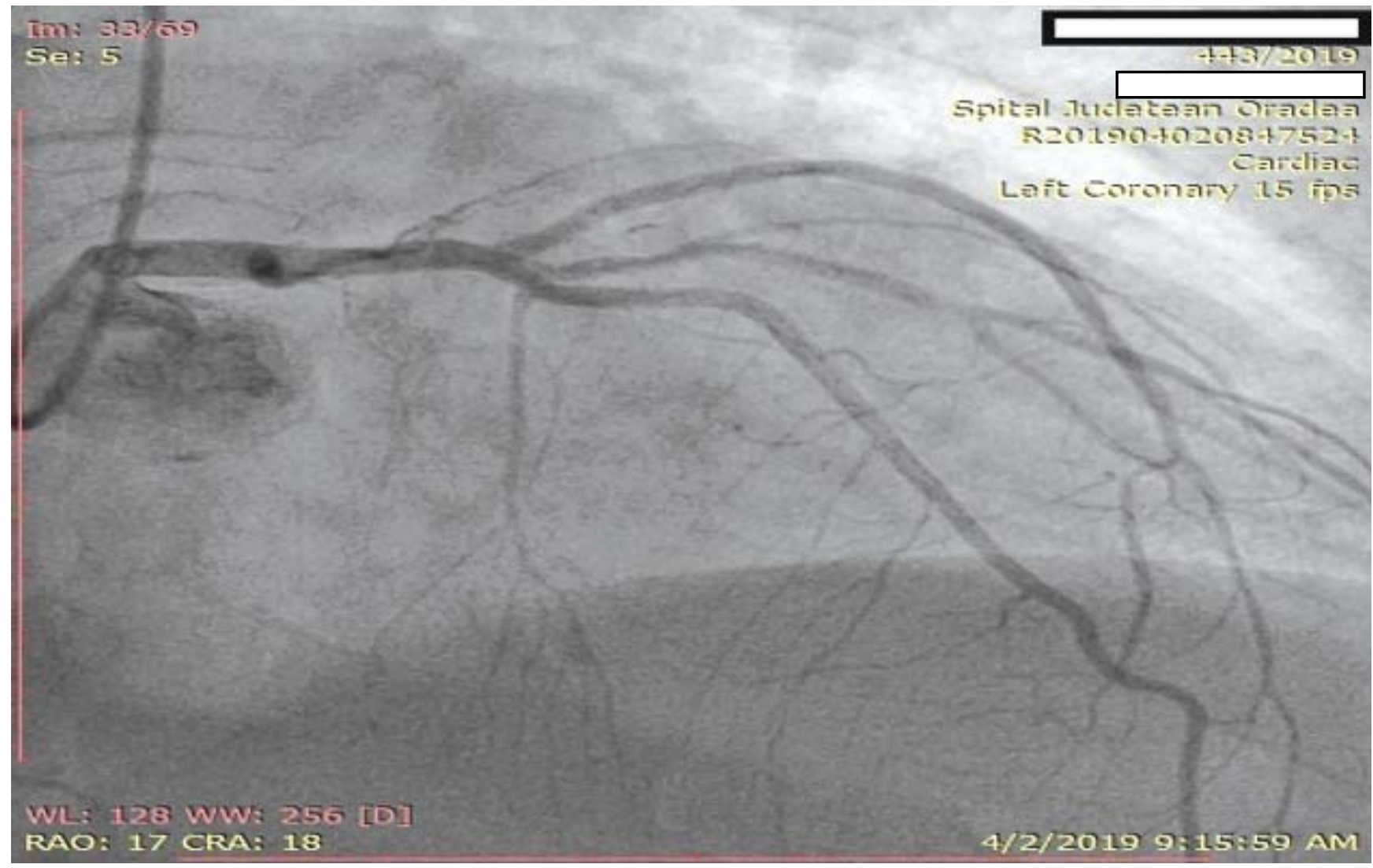

Figure 3. Angiography - Left and circumflex coronary arteries with no obstructive lesions. 


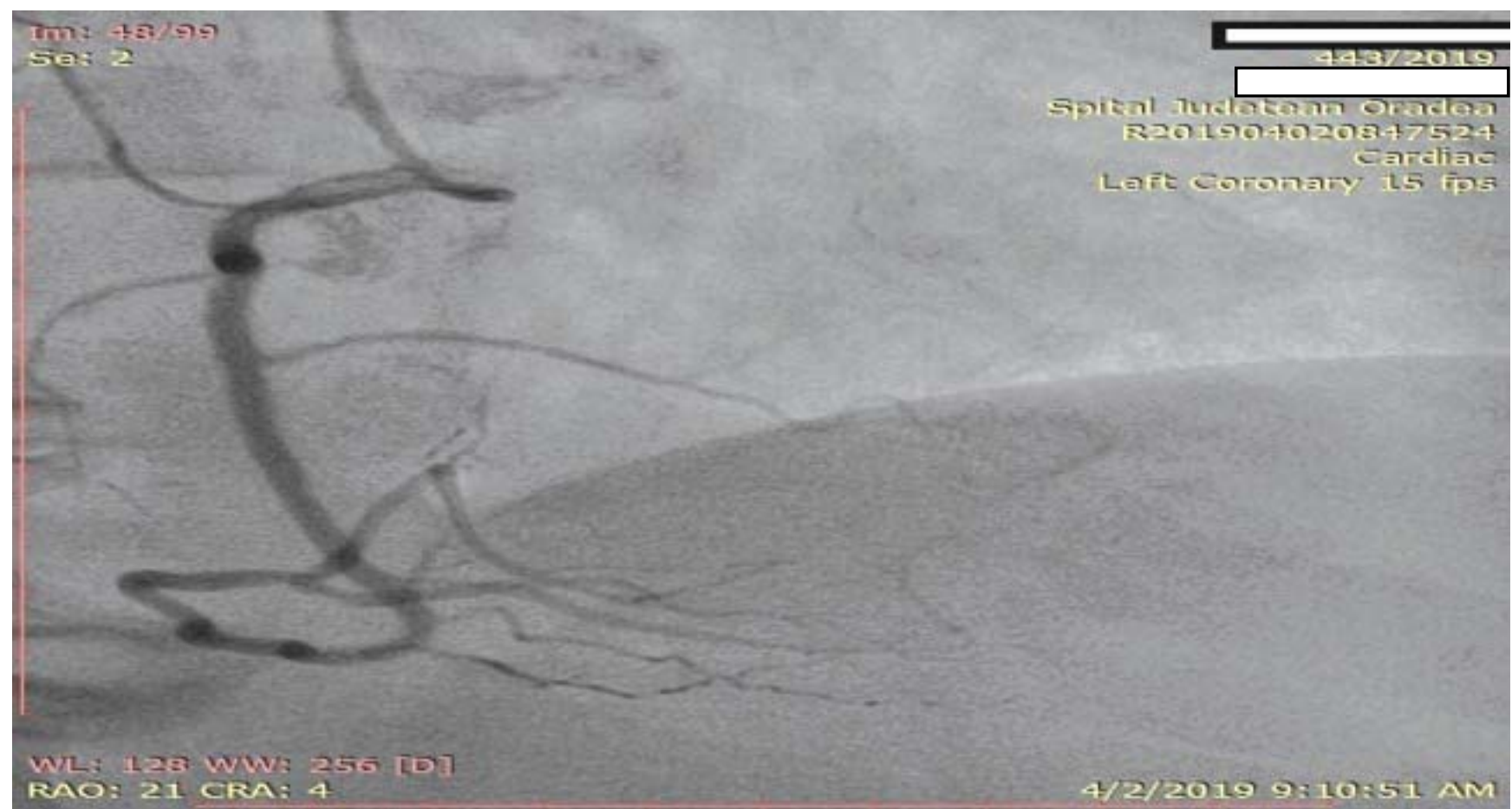

Figure 4. Angiography - Right coronary artery without significant stenosis.
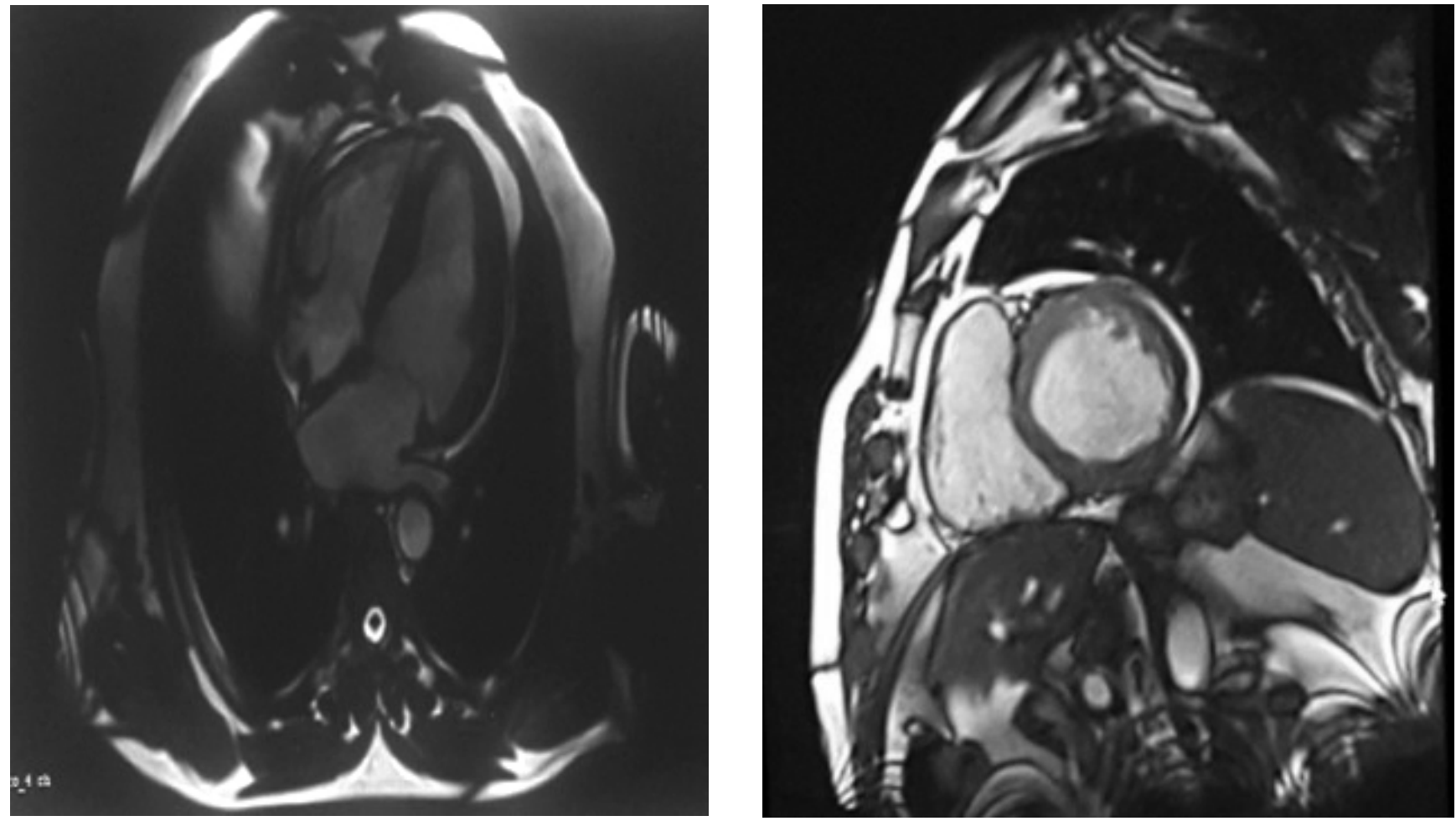

Figure 5. Cardiac MRI - vertical - long axis (left) and mid ventricular short axis (right) revealing lateral myocardial infarction due to late gadolinium enhancement caused by cellular necrosis. 
were found for the V HI299R (R2) factor, II G202I0A factor, XII V34L factor and PAI-I 4G/5G. In addition, there was a homozygous mutation of the MTHFR C677T, revealing a high predisposition for arterial and venous thrombosis.

In our opinion that the main underlying cause was an arterial thrombus even if the coronary angiography did not reveal this aspect, this would be the suitable explanations consistent with the cardiac MRI description. In situ formation and subsequent spontaneous lysis of a coronary artery thrombus represents a plausible mechanism involved in MINOCA syndrome.

The most challenging aspect regarding this case is represented by the identification of a proper treatment, considering the fact that the patient has the predisposition for both arterial and venous thrombosis and the existing trials are still debating whether there is certain indication of the direct oral anticoagulants (DOACs). Our option was antivitamin K drugs due to the fact that there are clinical trials with strong evidences regarding their reduction of thrombotic events in subjects with thrombophilia. Besides the oral anticoagulants, the treatment included antiplatelet therapy, diuretics, inhibitors of the angiotensin enzyme and insulin.

\section{DISCUSSIONS}

MINOCA syndrome should be faced as a working diagnosis and all the efforts should be directed towards finding the real underlying substrate. The outcome of this syndrome represents a serious problem, with an estimated one year mortality of $4.7 \%{ }^{4}$.

Investigations like cardiac magnetic resonance and coronary imaging accompanied by functional assessment are required for the etiological diagnosis of MINOCA.

An observational study involving MINOCA patients from the SWEDEHEART registry demonstrated that the reinfarction rate in these subjects was $6 \%$ during a mean follow-up of 4.3 years. The mortality rate was equally high after recurrent MINOCA, as compared to the myocardial infarction with significant coronary artery stenosis with an initial MINOCA episode. This idea reflects the fact that MINOCA is not a benign condition and patients who repeat the event will have a negative outcome ${ }^{5}$.

Another relevant registry, named VIRGO, expressed the fact that MINOCA is not a harmless condition, revealing that a similar number of both MINOCA and AMI with coronary artery disease experienced heart failure and cardiac arrest ${ }^{6}$.
Clear indications regarding the dual antiplatelet therapy in MINOCA are lacking. The MINOCA registry gathered 9.466 subjects without etiological diagnosis of this syndrome. This registry aimed to discover the optimal medical therapy for secondary prevention and the long-term outcome. The conclusion of this registry was that there is a long term benefit in using the ACE inhibitors or angiotensin II receptor blockers and a positive effect of the beta-blockers, but the dual antiplatelet therapy expressed a neutral effect ${ }^{4}$.

Data from randomized trials should be used to identify the optimal management of MINOCA, with a clear benefit on the secondary prevention.

The association between antiphospholipid syndrome (APS) and MINOCA incidence was revealed in an observational study. MINOCA rate had a higher incidence in subjects with antiphospholipid syndrome compared with the control group without APS ${ }^{7}$.

The indication of DOACs in MINOCA syndrome caused by thrombophilia remains controversial. There is only one trial which compared rivaroxaban with warfarin for secondary prevention of venous thromboembolism in patients with APS but the evidences were not strong enough to favors the usage of DOACs ${ }^{7}$.

Arterial thrombosis in patients with MINOCA and APS has indication of antivitamin $\mathrm{K}$, but there is a challenge in maintaining the INR between the recommended ranges because the APS may produce false elevation of the INR. The recurrent arterial thrombotic events despite a therapeutic INR may be solved by adding aspirin, statins or using a low-molecular-weight heparin ${ }^{8}$.

\section{CONCLUSIONS}

The etiological diagnosis of the MINOCA syndrome represents the essential key in finding the proper management of this condition. CMR had clear benefits in revealing the underlying cause of the MINOCA syndrome in our patient and gave us the clue to perform the genetic tests for thrombophilia.

Further randomized studies are required to establish whether the DOACs represent a better option than antivitamin $\mathrm{K}$ in patients with MINOCA and APS. We considered that antivitamin $K$ agents are the best therapeutic approach in this particular case, but the thrombotic event may repeat because there is still a challenge to maintain the INR in therapeutic ranges and offer the best antithrombotic protection.

Conflict of interest: none declared. 


\section{Referennces:}

I. Pasupathy S., Tavella R., Beltrame J.F. Myocardial Infarction With Nonobstructive Coronary Arteries (MINOCA) The Past, Present, and Future Management. Circulation. 2017;135:1490-1493.

2. Thygesen K., Alpert J.S., Jaffe A.S., Chaitman B.R. et al. Fourth universal definition of myocardial infarction. European Heart Journal. 2018, 40(3): 237-269.

3. Agewall S., Beltrame J.F., Reynolds H.R., Niessner A. et al. ESC working group position paper on myocardial infarction with non-obstructive coronary arteries, European Heart Journal, 2017, 38(3):143153.

4. Lindahl B, Baron T, Erlinge D, Hadziosmanovic $\mathrm{N}$ et al. Medical therapy for secondary prevention and longterm outcome in patients with myocardial infarction with nonobstructive coronary artery disease. Circulation. 2017;135:148I-|489.

5. Nordenskjold AM, Baron T, Eggers KM, Jernberg T, Lindahl B. Predictors of adverse outcome in patients with myocardial infarction with non-obstructive coronary artery (MINOCA) disease. Int J Cardiol. 2018;261:18-23.

6. Kochanek KD, Murphy SL, Xu J, Tejada-Vera B. Deaths: final data for 2014. Natl Vital Stat Rep. 2016;65:I-122.

7. Gandhi H., Ahmed N., Spevack D.M. Prevalence of myocardial infarction with non-obstructive coronary arteries (MINOCA) amongst acute coronary syndrome in patients with antiphospholipid syndrome. IJC Heart \& Vasculature. 2019,22:148-I49.

8. Garcia D., Erkan D. Diagnosis and Management of the Antiphospholipid Syndrome. N Engl ] Med 378;21:2010-2020. 